\title{
Integrated crop-livestock system with system fertilization approach improves food production and resource-use efficiency in agricultural lands
}

\author{
Gustavo Duarte Farias ${ }^{1}$ (D) Jose Carlos Batista Dubeux $\mathrm{Jr}^{2} \cdot$ Jean Víctor Savian ${ }^{3}$ - Lóren Pacheco Duarte ${ }^{1}$. \\ Amanda Posselt Martins ${ }^{4} \cdot$ Tales Tiecher $^{4} \cdot$ Lucas Aquino Alves $^{4} \cdot$ Paulo César de Faccio Carvalho ${ }^{1} \cdot$ Carolina Bremm $^{1}$
}

Accepted: 4 October 2020 / Published online: 27 October 2020

(C) INRAE and Springer-Verlag France SAS, part of Springer Nature 2020

\begin{abstract}
Integrated crop-livestock systems (ICLS) can be an alternative to increase the productivity of agroecosystems by enhancing nutrient cycling via grazing animals. Despite the holistic approach that bears the designing of ICLS, fertilization practices are proceeded in a conventional crop basis, disregarding nutrient fluxes at the appropriate spatial and temporal dynamics. We argue that fertilization practices in ICLS must follow the same integrated approach. To test this, we compared a conventional crop fertilization strategy versus a system fertilization approach applied to two production systems being a conventional cropping system and ICLS. The conventional cropping system consisted of a soybean crop succeeded by a non-grazed Italian ryegrass cover crop. The ICLS model consisted of a soybean-Italian ryegrass rotation grazed by sheep. In the conventional crop fertilization strategy phosphorus and potassium were applied at soybean sowing and nitrogen at the Italian ryegrass establishment. The system fertilization consisted of the application of all nutrients during the Italian ryegrass establishment. Accordingly, treatments were fertilization strategies in a factorial framework with production systems randomly distributed in a complete block design with four replicates. Results indicated for the first time greater daily herbage accumulation rate $(24 \% ; P<0.01)$ and total herbage production $(18 \% ; P<0.05)$ in the system fertilization compared with conventional crop fertilization. Consequently, system fertilization allowed for greater stocking rates in the pasture phase $(17 \% ; P<0.05)$. The ICLS presented greater equivalent soybean yield $(P<0.001)$, energy production $(P<0.01)$, and system productivity $(P<0.05)$ compared with the cropping system, regardless of fertilization strategies. Soybean yield was not affected by fertilization strategies or grazing. In conclusion, the adoption of system fertilization strategy and crop-livestock integration enhance the production without jeopardizing soybean grain yields, so that land use is optimized by a greater energy production per unit of nutrient applied.
\end{abstract}

Keywords Cropping systems $\cdot$ Grazing $\cdot$ Mixed crop-livestock systems $\cdot$ Nutrient cycling $\cdot$ Soybean $\cdot$ Crop fertilization

Gustavo Duarte Farias

gustavo.dfarias@hotmail.com

1 Department of Forage Plants and Agrometeorology, Integrated Crop-Livestock System Research Group (GPSIPA), Federal University of Rio Grande do Sul, Av. Bento Gonçalves 7712, Porto Alegre, RS 91540-000, Brazil

2 University of Florida - North Florida Research and Education Center, Marianna, FL, USA

3 Instituto Nacional de Investigación Agropecuaria (INIA), Programa Pasturas y Forrajes, Estación Experimental INIA Treinta y Tres, Ruta $8 \mathrm{~km} 281$, Treinta y Tres, Uruguay

4 Department of Soil Science, Interdisciplinary Research Group on Environmental Biogeochemistry (IRGEB), Federal University of Rio Grande do Sul, Bento Gonçalves, Av. Bento Gonçalves 7712, Porto Alegre, RS 91540-000, Brazil

\section{Introduction}

Human population and income have been increasing in the last decades and, simultaneously, the global requirement for animal source food is expected to rise soon (Mottet et al. 2017). Thus, production systems that supply large amounts of food to global markets will need to increase their production. In the current scenario, there is an increasing social and political pressure to preserve natural ecosystems, added to increasing urbanization, and the specialized commercial agroecosystem models with high use of non-renewable resources. These facts pose barriers to the expansion of agricultural frontiers to increase food, fiber, and energy production per unit of area and input (Lemaire et al. 2015). Specialized 
commercial agroecosystems such as the cropping system, although using conservation precepts (e.g., no-till), have low complexity and diversification, making it difficult to increase food production.

Integrated crop-livestock systems (ICLS) are a sustainable intensification alternative to specialized commercial agroecosystems. Hendrickson et al. (2008) defined sustainability as an approach to producing food and fiber which is profitable, and with resources-use efficiency on the farm. Thus, diverse agricultural production systems such as ICLS might ensure productive conditions in the future and enhance environmental quality. Grazing animals uncouple nutrients and return a large portion to the system via urine and dung (Haynes and Williams 1993). Hence, grazing management is a key factor affecting nutrient dynamics in grazed systems. Sound grazing management increases belowground biomass (López-Mársico et al. 2015), soil fauna, microbial diversity, and the functionality of these populations (Davinic et al. 2013). These are important factors affecting nutrient cycling and increasing $\mathrm{C}$ and $\mathrm{N}$ stocks (da Silva et al. 2014). Furthermore, ruminants are able to upscale human-inedible materials, such as grasses, into highly nutritious animal source food, such as meat and milk (Mottet et al. 2017). The integration of livestock into cropping systems has positive effects on the agroecosystem, minimizing environmental impacts due to synergisms between system components, with the benefit of increasing the food production per unit of land without converting natural habitats.

The knowledge of plant nutrient requirements and the use of inorganic fertilizer allow an increase in crop production. Annually, fertilizer demand is growing 1.4, 2.2, and 2.6\% for N, P, and K, respectively (FAO 2015). Therefore, there is a growing concern about the limited availability of mined fertilizers and the potential for contamination of water bodies. Boring et al. (2018) pointed out an increase in soybean and corn yields with phosphorus and potassium application on poor soils, but these responses have been irregular in soil with high nutrient levels. Currently, fertilizer recommendations target to meet crop needs and to increase soil nutrient levels above critical thresholds. Conserving the nutrients is key for agroecosystem success, and the grazing animal play a crucial function to nutrient cycling and can affect positively subsequent crops yields when managed under moderate grazing intensities (Sartor et al. 2018). Thus, a new approach of fertilization emerges - the system fertilization - which is based on the conceptual framework that fertilizer must be applied in the system phase that presents lower nutrient extraction and higher nutrient cycling capacity to maximize total system production (Assmann et al. 2017). This new approach considers all benefits of well-managed grazing during the pasture phase, including the reduced amounts of nutrients extracted by livestock and accelerated nutrient cycling returned to the soil via excreta (Haynes and Williams 1993). However, there is a lack of research evaluating the effects of system fertilization with phosphorus $\left(\mathrm{P}_{2} \mathrm{O}_{5}\right)$ and potassium $\left(\mathrm{K}_{2} \mathrm{O}\right)$ in ICLS and cropping systems.

The present study pairs a detailed analysis of system production dynamics of ICLS and cropping system under different fertilization strategies in Southern Brazil (Fig. 1). We hypothesized that ICLS with system fertilization (on pasture phase) results in greater herbage and animal production compared with conventional crop fertilization (on crop phase), without affecting crop grain yield. The objectives of this study were to evaluate the effect of cropping system (soybean monoculture and non-grazed Italian ryegrass cover crop) or ICLS (soybean monoculture and sheep grazing Italian ryegrass cover crop), and two fertilization strategies (system fertilization or crop fertilization) on herbage and animal production, soybean grain yield, total system production, and system productivity in terms of use of resources (inputs).

\section{Materials and methods}

\subsection{Site, climate, and soil description}

The experiment was conducted in 2017 and 2018 at the Experimental Agronomic Station of the Federal University of Rio Grande do Sul (EEA-UFRGS), in Eldorado do Sul, Rio Grande do Sul, southern Brazil (latitude $30^{\circ} 05^{\prime} \mathrm{S}$, longitude $51^{\circ} 39^{\prime} \mathrm{W}$ and $46 \mathrm{~m}$ of altitude).

The climate of the site is subtropical humid. Daily mean data on air temperature and rainfall were obtained from a nearby $(\sim 1 \mathrm{~km})$ meteorological station. Average air temperatures were 19.8 and $19.2^{\circ} \mathrm{C}$ in 2017 and 2018 , respectively, and annual rainfall was 1510 and $1214 \mathrm{~mm}$ in 2017 and 2018, respectively (Fig. 2).

The soil at the experimental site was classified as an Acrisol. At the beginning of the experimental protocol (2017), the soil diagnostic surface $(0-10 \mathrm{~cm})$ presented $17 \mathrm{~g}$ $\mathrm{kg}^{-1}$ of organic carbon, $\mathrm{pH}\left(\mathrm{H}_{2} \mathrm{O}\right)$ of $3.9,1.1 \mathrm{cmol} \mathrm{dm}^{-3} \mathrm{Ca}$, $0.5 \mathrm{cmol} \mathrm{dm}^{-3} \mathrm{Mg}, 15 \%$ of base saturation (V\%), $49 \%$ of $\mathrm{Al}$ saturation, and available phosphorus and potassium (extracted by Mehlich 1) of 94 and $97 \mathrm{mg} \mathrm{dm}^{-3}$, respectively. Based on the soil chemical analysis, $7.5 \mathrm{Mg} \mathrm{ha}^{-1}$ of dolomitic limestone $\left[\mathrm{CaMg}\left(\mathrm{CO}_{3}\right)_{2}\right]$ with a total neutralization power of $72 \%$ was applied to raise soil $\mathrm{pH}$ to 6.0 .

\subsection{Experimental design and treatments}

The experimental design was a randomized complete block in a factorial $2 \times 2$ with four replicates. Factors included two notill production systems: (i) soybean in crop phase and sheep grazing Italian ryegrass (Lolium multiflorum) cover crop in the pasture phase, consisting of an integrated crop-livestock system-ICLS, and (ii) soybean in crop phase and non-grazed 
Fig. 1 a Italian ryegrass (Lolium multiflorum) cover crop (non-grazed) in specialized system (cropping system). b Sheep grazing Italian ryegrass under moderate grazing intensity (15-cm sward canopy height) in the integrated crop-livestock system (ICLS). c Soybean (Glycine max) in the middle summer growing season (January)
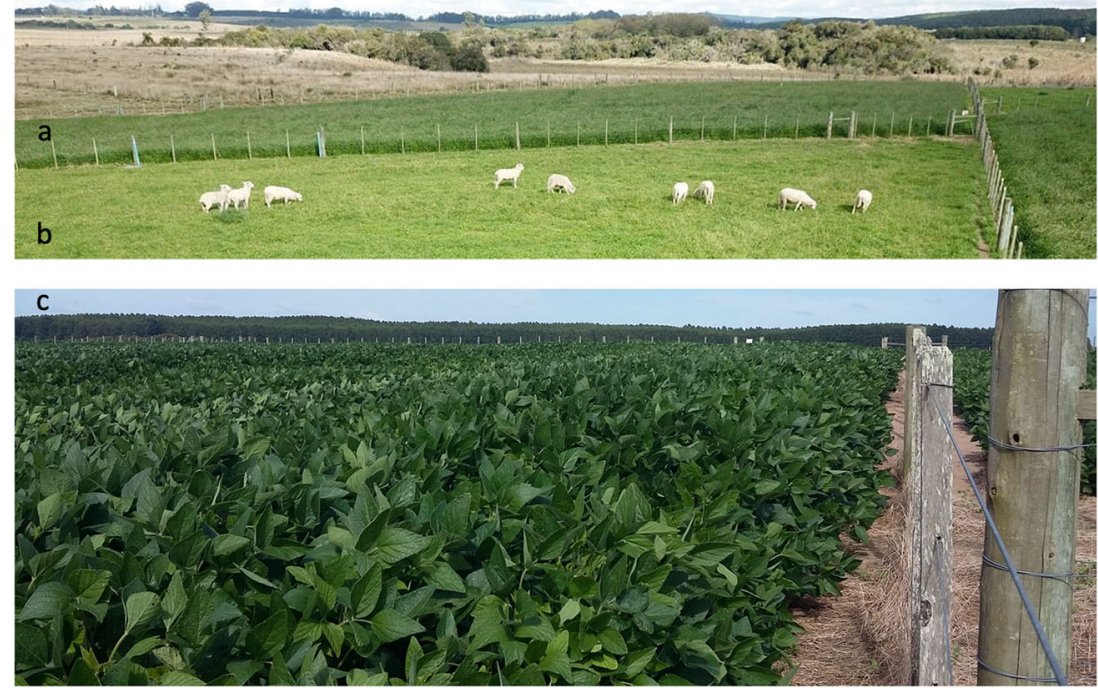

Italian ryegrass as cover crop in the pasture phase, consisting of a cropping system only, and two periods of phosphorus $\left(\mathrm{P}_{2} \mathrm{O}_{5}\right)$ and potassium $\left(\mathrm{K}_{2} \mathrm{O}\right)$ fertilization: (i) conventional crop fertilization, with the fertilizer applied in the soybean sowing, and (ii) system fertilization, with the fertilizer applied in the pasture establishment (Fig. 3). The $\mathrm{P}_{2} \mathrm{O}_{5}$ and $\mathrm{K}_{2} \mathrm{O}$ fertilization rates were calculated for a soybean grain production of $4.0 \mathrm{Mg} \mathrm{ha}^{-1}$. Nitrogen fertilization $\left(150 \mathrm{~kg} \mathrm{~N} \mathrm{ha}^{-1}\right)$ in the form of urea was performed once in all treatments on Italian ryegrass establishment. The experimental area was 4.4 ha, divided into 16 experimental units (paddocks), ranging between 0.23 and 0.32 ha each being large enough to avoid nutrient transfer between the experimental units.

\subsection{Pasture phase}

In both years, 2017 and 2018, the stocking period started in June and finished in October, totalizing 125 and 120 days of grazing, respectively. After soybean harvest, Italian ryegrass was sown ( $25 \mathrm{~kg}$ of viable pure seeds per ha). In ICLS treatments, the continuous stocking method with three tester sheep per paddock and a variable number of "put-and-take" sheep were used to maintain the targeted sward canopy height of 15 $\mathrm{cm}$. This grazing management strategy was defined to offer to the animal an optimal sward canopy structure to maximize herbage intake per unit of grazing time ("Rotatinuous" stocking; Carvalho (2013)).

\subsubsection{Sward measurements}

To maintain the desired sward canopy height, 150 random points per paddock were measured weekly with a sward stick. Herbage mass ( $\mathrm{kg} \mathrm{DM} \mathrm{ha}{ }^{-1}$ ) was measured in all paddocks prior to the beginning of the stocking period and every 28 days (subperiod). For this, six random forage samples $\left(0.25 \mathrm{~m}^{2}\right)$ per paddock were clipped at ground level. Daily herbage accumulation rate was evaluated by through the use of four grazing exclusion cages per paddock. At the beginning of each stocking period, herbage mass was determined by clipping at ground level $\left(0.25 \mathrm{~m}^{2}\right)$ at four random places and cages were allocated nearby. The cage places were chosen by similarity with herbage mass cut. Approximately 28 days after, the
Fig. 2 Annual average rainfall and mean air temperature at the Agronomy Experimental Station from Federal University of Rio Grande do Sul during the experimental period (2017-2018) and the long-term climatic means between 1970 and 2009

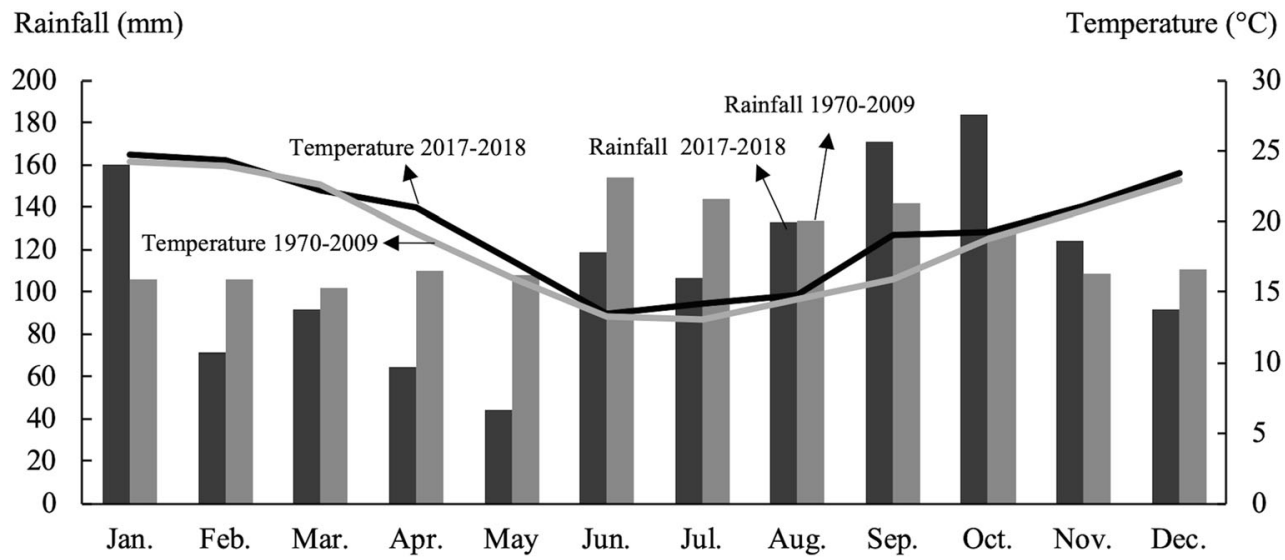



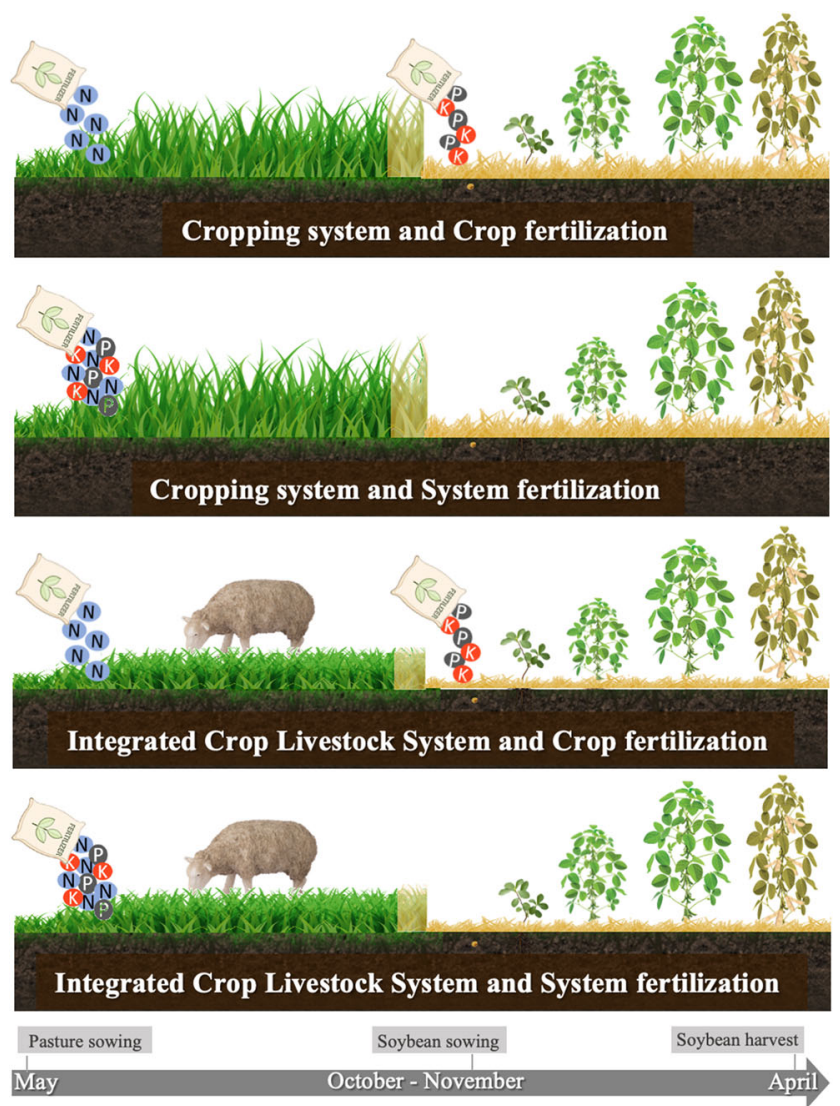

Fig. 3 Schematic representation of the treatments: cropping system or integrated crop-livestock system (ICLS) with crop fertilization or system fertilization in southern Brazil

herbage mass inside cages was cut at ground level as previously mentioned. Then, herbage samples were oven-dried at $55^{\circ} \mathrm{C}$ for $72 \mathrm{~h}$ and weighed for assessment of dry matter (DM) content. Daily herbage accumulation rate $\left(\mathrm{kg} \mathrm{DM} \mathrm{ha}^{-1}\right.$ day $\left.^{-1}\right)$ was calculated by the difference between the DM of the sampling dates divided by the period (days) between cuts. This process was performed in each subperiod.

Total herbage production $\left(\mathrm{kg} \mathrm{DM} \mathrm{ha}^{-1}\right)$ was calculated by the sum of herbage production in each subperiod (daily herbage accumulation rate $\left(\mathrm{kg} \mathrm{DM} \mathrm{ha}^{-1}\right.$ day $\left.^{-1}\right)$ multiplied by the number of days of each subperiod), and the initial herbage mass (evaluated 1 day before starting the stocking period). Finally, at the end of the stocking period, residual herbage mass $\left(\mathrm{kg} \mathrm{DM} \mathrm{ha}^{-1}\right)$ was estimated following the same methodology used to measure herbage mass.

\subsubsection{Animal measurements}

The study was approved and carried out in strict accordance with the recommendations of the Ethical Review Committee on the Use of Animals of the Federal University of Rio Grande do Sul, Brazil (project no 34358).

The animals were 11-month-old Corriedale castrated sheep, weighing $24.5 \pm 0.3 \mathrm{~kg}$ and $29.8 \pm 0.6 \mathrm{~kg}$ of live weight
(LW) at the beginning of the stocking period in 2017 and 2018 , respectively. Sheep were weighed after fasting from solids and liquids for approximately $12 \mathrm{~h}$. Average daily gain (ADG, $\mathrm{g}_{\text {animal }}{ }^{-1}$ day $^{-1}$ ) was calculated as the difference between final and initial LW of tester animals, divided by the number of days in each subperiod. Whenever necessary to put or take sheep to keep the target sward canopy management, these sheep were weighed, and their weights and time spent in the paddock were considered to the stocking rate calculation. The stocking rate ( $\mathrm{kg} \mathrm{LW} \mathrm{ha}{ }^{-1}$ day $^{-1}$ ) was calculated by the sum of average LW of testers and put-and-take animals, multiplied by the number of days that the animals remained in the paddock, expressed per unit area. The LW gain per hectare was obtained by the sum of sheep LW gain in each subperiod. For that, stocking rate (in number of animals per ha) was multiplied by the ADG of the tester sheep and by the number of days of the subperiod.

\subsection{Crop phase}

\subsubsection{Crop management}

In both years, after the stocking period, the Italian ryegrass was desiccated with glyphosate $\left(3 \mathrm{~L} \mathrm{ha}^{-1}\right)$ and saflufenacil $\left(100 \mathrm{~g} \mathrm{ha}^{-1}\right)$. Soybean seeds (Glycine max) were treated with insecticide and fungicide, inoculated and sown in rows spaced $0.45 \mathrm{~m}$ apart at a density of 36 seeds $\mathrm{m}^{-2}$, under no-tillage. Pest control in soybean crop was weekly monitored, and the use of herbicides, insecticides, and fungicides was conducted according to the technical recommendations. Soybean harvest occurred every April.

\subsubsection{Crop measurements}

Six areas per paddock were randomly chosen to measure the soybean grain yield $\left(\mathrm{kg} \mathrm{ha}^{-1}\right)$ in the phenological stage $\mathrm{R} 8$. For each sample, two-linear-meter $\left(0.9 \mathrm{~m}^{2}\right.$ per sample $)$ of soybean plants were clipped at ground level and the grains were harvested, weighted, and had their humidity measured. The soybean yield was estimated by multiplying the grain weight by ten thousand and dividing by the sample area $(0.9$ $\mathrm{m}^{2}$ ) and then multiplied by a correction factor to obtain soybean yield adjusted to $13 \%$ of humidity.

\subsection{System production and resource-use efficiency}

The system production was assessed in two ways, by calculating the equivalent soybean $\left(\mathrm{kg} \mathrm{ha}^{-1}\right)$ and equivalent energy $\left(\mathrm{Gj} \mathrm{ha}^{-1}\right)$ produced in each system phase. The sum of commercial prices of sheep and soybean sales in September and April respectively was divided by soybean sale prices to be expressed as equivalent soybean yields $\left(\mathrm{kg} \mathrm{ha}^{-1}\right)$. Product sale prices were obtained from the Management Planning Division 
of Rio Grande do Sul state, Brazil (Emater/Ascar), converted into U\$ by Central Bank of Brazil and used to calculus. System production in equivalent energy production $\left(\mathrm{GJ} \mathrm{ha}^{-1}\right.$ ) was obtained multiplying pasture phase production (total herbage production and sheep LW gain) and crop phase production (soybean yield) by their caloric values. The caloric values used were $18.05 \mathrm{MJ} \mathrm{kg}^{-1}$ for above-ground biomass (Fuksa et al. 2013), 13.1 $\mathrm{MJ} \mathrm{kg}^{-1}$ for meat sheep carcass (Silva et al. 2005), and $15.05 \mathrm{MJ} \mathrm{kg}^{-1}$ for soybean grain (Alimagham et al. 2017). The meat equivalent energy was measured multiplying LW gain by equivalent carcass $(44.1 \%$ of LW; Carvalho et al. (2006)), multiplying by the equivalent energy. The system productivity was obtained by system production, in equivalent energy production ( $\mathrm{Gj} \mathrm{ha}{ }^{-1}$ ), divided by inputs ( $\mathrm{kg}$ of $\mathrm{N}, \mathrm{P}_{2} \mathrm{O}_{5}$, and $\mathrm{K}_{2} \mathrm{O}$ ) applied in the system. A system that presented greater productivity compared with other was considered more efficient in the use of resources.

\subsection{Data analysis}

The assumptions of the analysis of variance (ANOVA) were achieved (normality by Shapiro test $(P>0.05)$, variance homogeneity by Bartlett test $(P>0.05)$, and visual residual analysis). The ANOVA was run using a mixed model by LMER function of package lme4 in R Studio software (v.3.6.0). The production system (grazed vs. non-grazed), fertilization strategy effect (crop fertilization vs. system fertilization), and their interaction was considered fixed effects. Random effects included block, subperiod, and year. The subperiod effect was included in the model for response variables evaluated every 28 days. For animal performance, fertilization strategies were considered fixed effect, and block, subperiod and year, as random effects. Animal performance per area included fertilization strategies as fixed effect and block and year as random effects. For herbage production, soybean yield, system production and productivity, fertilization strategy, and their interaction were fixed effects and random effects were block and year.

\section{Results and discussion}

Pasture variables presented no interaction $(P>0.05)$ between fertilization strategies and production systems (Table 1). An important factor to assign the results to the effects of treatments is the pasture baseline. In that regard, initial herbage mass did not differ $(P=0.55)$ between treatments. Average sward canopy height during the pasture phase was greater $(P<$ 0.01 ) for the cropping system (non-grazed) than for the ICLS (grazed) treatments. This result was expected due to free plant growth in the absence of grazing, leading to faster internode elongation and early flowering, compared with grazed areas that extended the plant vegetative growing period (Rocha et al. 2004). However, the sward canopy height between ICLS treatments with different fertilization strategies was similar $(\sim 16 \mathrm{~cm} ; P=0.85)$ and close to the target of moderate grazing intensity proposed in this study. Since herbage mass and sward canopy height are linearly related (Kunrath et al. 2020), herbage mass in our study did not differ $(P>0.05)$ between fertilization strategies (Table 1).

The pasture results show that sheep were kept in similar grazing conditions, so average daily gain (ADG) was similar $(P=$ 0.21 ) between treatments (Table 1). Assuming that herbage intake was similar as a consequence of successful sward canopy height control, the only difference in ADG would come from herbage chemical quality. Therefore, despite possible differences in nutrient composition that were not studied here, the similarity for ADG regardless of the fertilization strategy suggests that sward structure prevails over herbage chemical quality. Results are in agreement with Carvalho et al. (2018), who argued grazing intensity as a major factor influencing animal performance in ICLS via sward canopy height, which affects the bite mass and, consequently, the herbage intake.

Well-managed pastures kept sufficient leaves after being grazed and stimulate the regrowth of new tillers that were previously shaded, increasing the productivity of the entire plant community (Lemaire 2001). This process can explain the greater daily herbage accumulation rate $(+27 \%$; $P<$ $0.01)$ and total herbage production $(+20 \% ; P<0.05)$ obtained in the ICLS compared with the cropping system. Nunes et al. (2019) observed similar results when evaluating the herbage accumulation in ICLS. They found higher daily herbage accumulation rate and total herbage production under moderate to light grazing intensities (20 to $40 \mathrm{~cm}$ sward canopy height) compared with non-grazed areas of mixed black oat (Avena strigosa) and Italian ryegrass pastures.

The system fertilization approach promoted greater herbage accumulation rate $(+24 \% ; P<0.01)$ and total herbage production $(+18 \% ; P<0.05)$ compared with the conventional crop fertilization (Table 1). According to Lemaire et al. (2019), N supply increases P demand by plants. This could explain our results, being that, when $\mathrm{N}, \mathrm{P}$, and $\mathrm{K}$ were applied in system fertilization, the $\mathrm{N}$ increase $\mathrm{P}$ and $\mathrm{K}$ demand which in this system (with system fertilization) the plant had easy availability compared with crop fertilization. In addition, Grant et al. (2001) suggested that plants subjected to low soil temperatures have a greater requirement for the more easily obtainable nutrient. In our experimental site, the lower temperatures occur during the pasture phase and the system fertilization strategy provides soluble $\mathrm{P}$ and $\mathrm{K}$. The increase in total herbage production resulted in a greater stocking rate (+ $17 \% ; P<0.05)$ to keep the targeted sward canopy height at system fertilization compared with crop fertilization (Table 1). However, this difference was not enough to impact LW gain per area $(P>0.05)$ even though system fertilization presented $\sim 9 \%$ greater compared with crop fertilization. 
Table 1 Characteristics and average production in the first two years of pasture and crop phases in an integrated crop-livestock system or cropping system with crop or system fertilization in southern Brazil.

\begin{tabular}{|c|c|c|c|c|c|c|c|}
\hline \multirow[t]{2}{*}{ Variables } & \multicolumn{2}{|l|}{ ICLS } & \multicolumn{2}{|c|}{ Cropping system } & \multirow[t]{2}{*}{$P_{\mathrm{F}}$} & \multirow[t]{2}{*}{$P_{A}$} & \multirow[t]{2}{*}{$P_{\mathrm{Fx} A}$} \\
\hline & $\mathrm{SF}$ & $\mathrm{CF}$ & $\mathrm{SF}$ & $\mathrm{CF}$ & & & \\
\hline \multicolumn{8}{|l|}{ Herbage (pasture phase) } \\
\hline Sward canopy height $(\mathrm{cm})$ & $16.2 \pm 0.3$ & $16.3 \pm 0.3$ & $37.6 \pm 2.3$ & $37.9 \pm 1.8$ & ns & $* * *$ & ns \\
\hline Initial herbage mass $\left(\mathrm{kg} \mathrm{DM} \mathrm{ha}{ }^{-1}\right)$ & $1258 \pm 103$ & $1374 \pm 87$ & $1367 \pm 149$ & $1615 \pm 152$ & ns & ns & ns \\
\hline Herbage mass $\left(\mathrm{kg} \mathrm{DM} \mathrm{ha}{ }^{-1}\right)$ & $2220 \pm 114$ & $2200 \pm 131$ & $3688 \pm 309$ & $4065 \pm 271$ & ns & $* * *$ & ns \\
\hline Daily herbage accumulation rate $\left(\mathrm{kg} \mathrm{DM} \mathrm{ha}^{-1}\right)$ & $67.3 \pm 4.2$ & $57.7 \pm 4.8$ & $56.6 \pm 7.2$ & $42.2 \pm 7.1$ & $* *$ & $* *$ & ns \\
\hline Total herbage production $\left(\mathrm{kg} \mathrm{DM} \mathrm{ha}^{-1}\right)$ & $9395 \pm 407$ & $8061 \pm 488$ & $7897 \pm 862$ & $6629 \pm 596$ & $*$ & $*$ & ns \\
\hline Residual herbage mass $\left(\mathrm{kg} \mathrm{DM} \mathrm{ha}^{-1}\right)$ & $3002 \pm 154$ & $2763 \pm 102$ & $5735 \pm 570$ & $5504 \pm 570$ & $\mathrm{~ns}$ & $* * *$ & $\mathrm{~ns}$ \\
\hline \multicolumn{8}{|l|}{ Animal (pasture phase) } \\
\hline Average daily gain $\left(\mathrm{g}\right.$ sheep ${ }^{-1}$ day $^{-1}$ ) & $123 \pm 11.7$ & $134 \pm 11.5$ & - & - & ns & - & - \\
\hline Stocking rate $\left(\mathrm{kg} \mathrm{LW} \mathrm{ha}{ }^{-1}\right)$ & $872 \pm 57.1$ & $745 \pm 52.0$ & - & - & * & - & - \\
\hline Live weight gain $\left(\mathrm{kg} \mathrm{ha}^{-1}\right)$ & $337 \pm 9.1$ & $310 \pm 27.2$ & - & - & ns & - & - \\
\hline \multicolumn{8}{|l|}{ Soybean (crop phase) } \\
\hline Soybean yield $\left(\mathrm{kg} \mathrm{ha}^{-1}\right)$ & $2730 \pm 172$ & $3019 \pm 135$ & $2920 \pm 163$ & $2877 \pm 212$ & ns & ns & ns \\
\hline \multicolumn{8}{|l|}{ System production (pasture + crop phase) } \\
\hline Eq. soybean yield $\left(\mathrm{kg} \mathrm{ha}^{-1}\right)$ & $4537 \pm 140$ & $4652 \pm 186$ & $2920 \pm 163$ & $2877 \pm 212$ & ns & $* * *$ & ns \\
\hline Eq. energy production $\left(\mathrm{GJ}_{\mathrm{Ja}}{ }^{-1}\right)$ & $212.7 \pm 6.1$ & $192.1 \pm 8.7$ & $150.8 \pm 25.1$ & $162.9 \pm 13.1$ & ns & $* *$ & ns \\
\hline
\end{tabular}

$I C L S$ integrated crop-livestock system, $S F$ system fertilization, $C F$ crop fertilization, $D M$ dry matter, $L W$ live weight, $P_{F}$ significance level for fertilization effect, $P_{A}$ significance level for animal effect (ICLS or cropping system), $P_{F x A}$ significance level for interaction between fertilization and animal effect (ICLS or cropping system), $n s$ not significant

$* P<0.05 ; * * P<0.01 ; * * * P<0.001$

The residual herbage mass presented no interaction between fertilization strategies and production systems $(P=0.98$; Table 1), and no difference was found for the fertilization strategies $(P>0.05)$. Results reaffirm the successful sward canopy height control up to the end of the stocking period. A key factor affecting agroecosystem sustainability is the presence of crop residues on the soil. These residues allow soil protection from direct rainfall impact, avoid compaction due to machinery traffic and animal trampling, water, and wind erosion, and improve soil organic matter developing better conditions for plants to grow. Considering the comparison between ICLS and cropping system, the presence of grazing animals has an obvious consequence on decreasing average herbage mass and residual herbage mass $(P<$ 0.01 ) in the ICLS compared with the cropping system (Table 1). The residual herbage mass is an important variable of connection between pasture and crop phases in no-till systems (Kunrath et al. 2020). However, although the ICLS presented lower residual herbage mass ( $\left.2882 \mathrm{~kg} \mathrm{DM} \mathrm{ha}^{-1}\right)$, no effect $(P=0.88)$ was found in the soybean grain yield compared with the cropping system $\left(5620 \mathrm{~kg} \mathrm{DM} \mathrm{ha}^{-1}\right)$.

Grazing decreases residual herbage mass to crop in succession, making farmers resist to the idea of including animals in cropping systems. However, ICLS have benefits that sometimes are not easy to notice in the short-term. According to Carvalho et al. (2018), animal contributions to system resilience are more evident over the long term. Grazing stimulates greater root production, increasing exudation of root organic compounds that promote the increase in microbial biomass (Davinic et al. 2013). Also, livestock excreta (urine and dung) improve litter quality and grazing might increase 1.5 -fold the carbon exudation from grazed plants (Hamilton et al. 2008). This process increases the rhizospheric decomposer community resulting in a 5-fold rhizospheric daily net mineralization rate. Furthermore, Peterson et al. (2019) evaluating a 16-year experiment pointed out that beef cattle managed under moderate grazing intensity (2500-4000 kg residual DM ha ${ }^{-1}$ ) in the pasture phase of an ICLS does not affect soybean yield, despite the lower water content in the soil when compared with non-grazed areas (6000-8000 kg residual DM ha ${ }^{-1}$ ). Thus, the soybean plants, sensitive to abiotic factors as rain-fed conditions, kept your production even in lower soil water condition compared with the cropping system, in long term under ICLS could improve grain yield (Carvalho et al. 2018).

\subsection{System production and resource-use efficiency}

Diversity and trophic complexity in agroecosystems are important factors in conservation agriculture, affecting system 
sustainability over-time. These systems increase the production from an existing agricultural land reducing risks and environmental impact by the diversification and complexity (Carvalho et al. 2018) that are inherent properties of natural agroecosystems. In this study, we contrasted for the first time ICLS and cropping system using a system fertilization approach compared with the conventional crop fertilization. Animal grazing (ICLS) and system fertilization affect positively herbage production without decreasing soybean yield. This is an important result since soybean is a summer crop with high demand on soil fertility and highly responsive to grain yield with fertilizer application. This shows that fertilizers applied in the pasture phase were kept on soil and were easily obtained by soybean plants. In addition, the system fertilization strategy potentially improves the efficiency of crop sowing operations by decreasing the time spent with reloading the planter with fertilizer (Assmann et al. 2017). Carvalho et al. (2018) analyzed the impact of introducing grazing to cover crops in rotation with grain crops and found out that grazing cover crops improved the yield of the following grain crops by $3.4,4.7,10.4$, and $10.8 \%$ on average to soybean, bean, irrigated rice, and maize, respectively. The authors argue that reports indicating the superiority of crop yield of non-grazed areas compared with grazed areas are rare, and commonly associated with the use of inappropriate grazing intensity.

Although soybean yield in our study was not different $(P>$ 0.05 ), when the LW gain of the ICLS is converted to equivalent soybean grains and added to soybean yield, the result represent an increase in 58\% $(P<0.001)$ to ICLS compared with cropping system (Table 1). These results corroborate with data reported by Carvalho et al. (2018) who found $60 \%$ greater soybean grain equivalent in the ICLS compared with the cropping system in a long-term study.

The ICLS had greater energy production $(P<0.05)$ compared with the cropping system, regardless of fertilization strategy (Table 1), with no interaction between factors $(P>$ $0.05)$. Greater energy production was attributed to two factors: greater herbage production added to animal production. The animal grazing is the key to this system due to the capacity to convert herbage in the highly nutritious human-edible food sources. Besides removing nutrients by intake and returning them via excretion, the grazing animal has the capacity to convert plant organic nutrients to inorganic nutrients during the digestion process (Haynes and Williams 1993). These authors found $80 \%$ of inorganic $\mathrm{P}$ in the dung of animals that ingested plant material with $64 \%$ of inorganic P. Dung is a source of labile nutrients, which may increase microbial biomass (Hatch et al. 2000). This allows rapid access to nutrients by microorganisms and growing plants. Moreover, livestock makes a necessary and important contribution to global nutrition, contributing $17 \%$ of calories and $33 \%$ of protein (FAO 2019).

The need to increase food production to meet the demand of a growing population has led to an increase in the use of human-edible feed ingredients, such as soybeans and cereals, in the ruminant sector. This is a concern, since it increases the competition with the human population for a limited global supply of grain crops, adding to the already existing demand for grains by the monogastric animal production sector (Wilkinson and Lee 2018). Southern Brazil has approximately 15 million ha of land under agricultural use (CONAB 2019). From this area, only 1.95 million ha $(13 \%)$ is integrated with livestock (Embrapa 2016) and approximately 4.7 million ha (31\% of total agricultural land) covered with winter cereal crops (CONAB 2019), resulting in $44 \%$ of agricultural land used during the winter season. Thus, it is possible to explore $56 \%$ ( $~ 8.4$ million ha) of agricultural land to food production in Southern Brazil. Considering the average animal performance from this study, the 8.4 million ha that are currently not used during the winter season in Southern Brazil could produce 1.2 billion $\mathrm{kg}$ of sheep carcass in well-managed

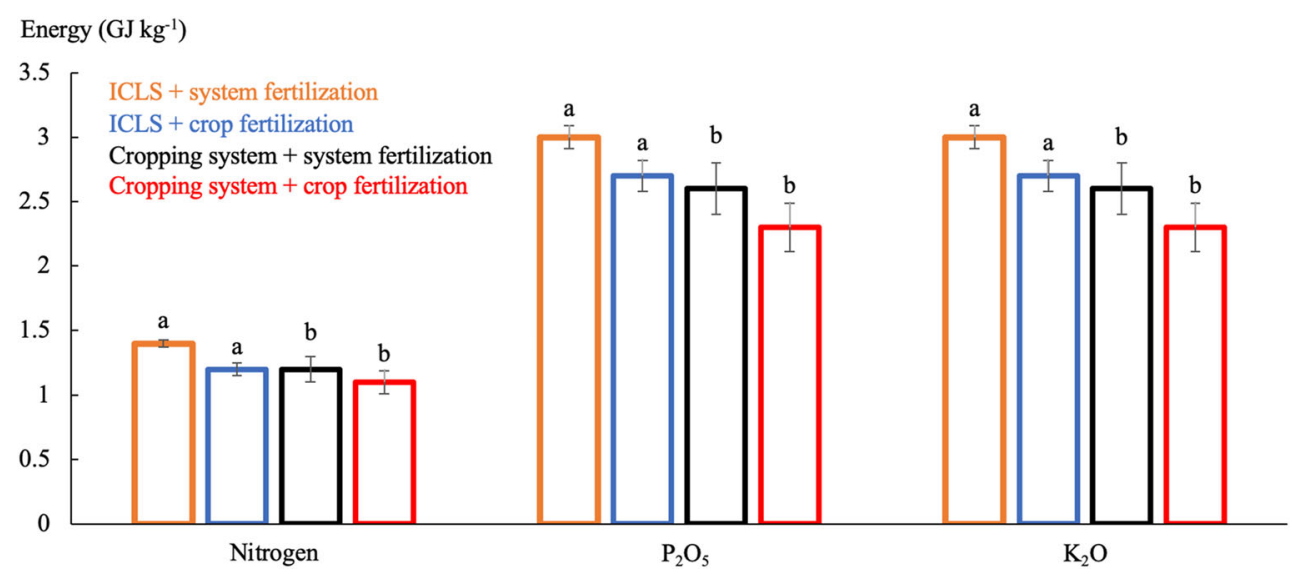

Fig. 4 Energy produced by input (kilogram of Nitrogen, $\mathrm{P}_{2} \mathrm{O}_{5}$ and $\mathrm{K}_{2} \mathrm{O}$ ) applied (2017/2018 and 2018/2019) in an integrated crop-livestock system (ICLS) or cropping system with the system or crop fertilization

in southern Brazil. The different letters are the significance level at $5 \%$ of the production system effect (ICLS versus cropping system) 
pastures without using human-edible feed resources or expanding the agricultural area. Our study illustrates a fattening system typical of Southern Brazil where sheep are purchased early in the winter and sold for slaughter at the end of the stocking period. However, there are several ways to explore this kind of integration in real farms, such as rearing females for herd replacement in full-cycle ranches where forage is scarce in the winter period.

In addition to increasing production and contributing to the global food supply, it is necessary to be more efficient in input use. Improvements in resource-use efficiency can be achieved through technology, animal health, management, and feed crop varieties (FAO 2019). Thus, we investigated how the inclusion of grazing on cover crops (ICLS) and the application of a new conceptual model of fertilization (system fertilization) would affect system productivity in terms of energy production per unit of nutrient input and how efficient these systems could be in the use of these resources (Fig. 4). In this sense, the system productivity efficiency $\left(\mathrm{Gj} \mathrm{kg}\right.$ fertilizer $\left.{ }^{-1}\right)$ did not present interaction between production system and fertilization strategy $(P>0.05)$. Moreover, even though the efficiency of nutrient use was not affected by fertilization strategies $(P=0.07)$, system fertilization was $12 \%$, on average, more efficient in the use of $\mathrm{N}, \mathrm{P}_{2} \mathrm{O}_{5}$ and $\mathrm{K}_{2} \mathrm{O}$ compared with crop fertilization. In addition, ICLS presented 15 and $17 \%$ more efficient in the use of $\mathrm{N}$ and $\mathrm{P}_{2} \mathrm{O}_{5}$ compared with the cropping system $(P<0.05)$. Similar result was found for $\mathrm{K}_{2} \mathrm{O}(P<0.05)$, which produced $2.9 \pm 0.08$ and $2.2 \pm 0.19 \mathrm{GJ}$ $\mathrm{kg} \mathrm{K}_{2} \mathrm{O}^{-1}$ for ICLS and cropping system, respectively.

Despite Brazilian farmer's perceptions that the integration of grazing animals into cropping systems is detrimental to crop production (Carvalho et al. 2018), our results show the positive effects of well-managed grazing of cover crops in ICLS on increasing total energy produced per unit area and improving fertilizer use efficiency. According to FAO (2019), greater input use efficiency is a crucial strategy for decoupling growth in the livestock sector to environmental impact. It is important to highlight that the crop and livestock integration do not impair the production system; on the contrary, these integrated systems when well-managed are beneficial and important for the world food production in the future.

\section{Conclusions}

Our findings highlight for the first time that system fertilization strategy and integrated crop-livestock systems (ICLS) results in greater herbage production without affecting soybean yield. Sheep production makes these systems more productive and efficient in the use of resources through the production of high-quality food. Finally, we believe that the specialized systems as a cropping system could be unsustainable in the near future, and the ICLS with well-managed pastures and system fertilization strategy in soils with high nutrient levels are a potential and necessary pathway to increase food production, improving the land use sustainability and productivity without increasing agriculture expansion and/or deforestation, which in our view should be considered as a climatesmart agriculture strategy.

Acknowledgments The authors are grateful to the farm staff at Agronomy Experimental Station of the Federal University of Rio Grande do Sul, the members of the Grazing Ecology Research Group (GPEP), Aliança SIPA for their invaluable assistance and comments, Interdisciplinary Research Group on Environmental Biogeochemistry (IRGEB), and the support of YARA Brasil.

\section{Compliance with ethical standards}

Funding The study was funded by Fundação Agrisus-Project PA2240/17 and Coordenação de Aperfeiçoamento de Pessoal de Nível Superior- Brasil (CAPES) - Finance Code 001.

Conflict of interest The authors declare that they have no conflict of interest.

Authors' contribution Conceptualization, P.C.F.C., C.B., G.D.F., T.T., and A.P.M.; Formal analysis, G.D.F and C.B.; Investigation, G.D.F., L.P.D., J.V.S., and L.A.A.; Data Curation, G.D.F., C.B., J.V.S., and L.P.D.; Writing — original draft, G.D.F.; Writing - review and editing, G.D.F., J.V.S., P.C.F.C., J.C.B.D., C.B., T.T., L.A.A. and A.P.M.; Visualization, G.D.F., Project administration, G.D.F. and L.A.A.; Supervision, C.B. and P.C.F.C.

\section{References}

Alimagham SM, Soltani A, Zeinali E, Kazemi H (2017) Energy flow analysis and estimation of greenhouse gases (GHG) emissions in different scenarios of soybean production (Case study: Gorgan region, Iran). J Clean Prod 149:621-628. https://doi.org/10.1016/j. jclepro.2017.02.118

Assmann TS, Soares AB, Assmann AL, et al (2017) Adubação de Sistemas em Integração Lavoura-Pecuária. In: Congresso Brasileiro de Sistemas Integrados de Produção Agropecuária e Encontro de Integração Lavoura-Pecuária no Sul do Brasil, 4, p. 67-84, ISBN - 978-85-99584-10-1. Disponível em: http://www. pb.utfpr.edu.br/coagr/eventos

Boring TJ, Thelen KD, Board JE, de Bruin J, Lee C, Naeve S, Ross W, Kent W, Ries L (2018) Phosphorus and potassium fertilizer application strategies in corn-soybean rotations. Agronomy 8:1-12. https://doi.org/10.3390/agronomy8090195

Carvalho PCF (2013) Can grazing behaviour support innovations in grassland management? Trop Grassl-Forrajes Trop 1:137-155

Carvalho PC d F, Barro RS, Barth Neto A et al (2018) Integrating the pastoral component in agricultural systems. Rev Bras Zootec 47. https://doi.org/10.1590/rbz4720170001

Carvalho PCDF, Oliveira JOR, Pontes LDS et al (2006) Características de carcaça de cordeiros em pastagem de azevém manejada em diferentes alturas. Pesqui Agrop Bras 41:1193-1198

Carvalho PC d F, Peterson CA, Nunes PA d A et al (2018) Animal production and soil characteristics from integrated crop-livestock systems: toward sustainable intensification. J Anim Sci. 96:35133525. https://doi.org/10.1093/jas/sky085 
CONAB (2019) Acompanhamento da safra brasileira de grãos: Séries históricas

da Rocha MG, Montagner DB, dos Santos DT et al (2004) Parâmetros produtivos de uma pastagem temperada submetida a alternativas de utilização. Rev Bras Zootech 33:1386-1395. https://doi.org/10. 1590/S1516-35982004000600005

da Silva FD, Amado TJC, Ferreira AO et al (2014) Soil carbon indices as affected by 10 years of integrated crop-livestock production with different pasture grazing intensities in Southern Brazil. Agric Ecosyst Environ 190:60-69. https://doi.org/10.1016/j.agee.2013. 12.005

Davinic M, Moore-Kucera J, Acosta-Martínez V, Zak J, Allen V (2013) Soil fungal distribution and functionality as affected by grazing and vegetation components of integrated crop-livestock agroecosystems. Appl Soil Ecol 66:61-70. https://doi.org/10.1016/ j.apsoil.2013.01.013

Embrapa (2016) Integração Lavoura-Pecuária-Floresta em números. Empresa Brasileira de Pesquisa Agropecuária. Disponível em: https://ainfo.cnptia.embrapa.br/digital/bitstream/item/158636/1/ 2016-cpamt-ilpf-em-numeros.pdf

FAO (2015) World fertilizer trends and outlook to 2018. Food and Agriculture Organization of the United Nations. Rome, Italy

FAO (2019) Production and Resources. Climate-smart livestock production. Food and Agriculture Organization of the United Nations, Rome

Fuksa P, Hakl J, Brant V (2013) Energy balance of catch crops productionTarpiniu augalu produkcijos energinis balansas. Zemdirbyste-Agriculture 100:355-362. https://doi.org/10.13080/za.2013.100.045

Grant CA, Flaten DN, Tomasiewicz DJ, Sheppard SC (2001) The importance of early season phosphorus nutrition. Can J Plant Sci 81:211224. https://doi.org/10.4141/P00-093

Hamilton EW, Frank DA, Hinchey PM, Murray TR (2008) Defoliation induces root exudation and triggers positive rhizospheric feedbacks in a temperate grassland. Soil Biol Biochem 40:2865-2873. https:// doi.org/10.1016/j.soilbio.2008.08.007

Hatch DJ, Lovell RD, Antil RS, Jarvis SC, Owen PM (2000) Nitrogen mineralization and microbial activity in permanent pastures amended with nitrogen fertilizer or dung. Biol Fertil Soils 30:288 293. https://doi.org/10.1007/s003740050005

Haynes R, Williams P (1993) Nutrient cycling and soil fertility in the grazed pasture ecosystem. In: Advances in Agronomy. pp 119-199

Hendrickson JR, Hanson JD, Tanaka DL, Sassenrath G (2008) Principles of integrated agricultural systems: Introduction to processes and definition. Renew Agric Food Syst 23:265-271. https://doi.org/10. 1017/S1742170507001718
Kunrath TR, Nunes PA d A, de Souza Filho W et al (2020) Sward height determines pasture production and animal performance in a longterm soybean-beef cattle integrated system. Agric Syst 177:102716. https://doi.org/10.1016/j.agsy.2019.102716

Lemaire G (2001) Ecophysiology of grasslands: dynamic aspects of forage plant population in grazed swards. In: International Grassland Congress. São Pedro, pp 29-37

Lemaire G, Gastal F, Franzluebbers A, Chabbi A (2015) Grasslandcropping rotations: an avenue for agricultural diversification to reconcile high production with environmental quality. Environ Manage 56:1065-1077. https://doi.org/10.1007/s00267-015-0561-6

Lemaire G, Sinclair T, Sadras V, Bélanger G (2019) Allometric approach to crop nutrition and implications for crop diagnosis and phenotyping. A review. Agron Sustain Dev 39:27. https://doi.org/10.1007/ s13593-019-0570-6

López-Mársico L, Altesor A, Oyarzabal M, Baldassini P, Paruelo JM (2015) Grazing increases below-ground biomass and net primary production in a temperate grassland. Plant Soil 392:155-162. https://doi.org/10.1007/s11104-015-2452-2

Mottet A, de Haan C, Falcucci A, Tempio G, Opio C, Gerber P (2017) Livestock: On our plates or eating at our table? A new analysis of the feed/food debate. Glob Food Sec 14:1-8. https://doi.org/10.1016/j. gfs.2017.01.001

Nunes PA d A, Bredemeier C, Bremm C et al (2019) Grazing intensity determines pasture spatial heterogeneity and productivity in an integrated crop-livestock system. Grassl Sci 65:49-59. https://doi.org/ 10.1111/grs.12209

Peterson CA, Nunes PA d A, Martins AP et al (2019) Winter grazing does not affect soybean yield despite lower soil water content in a subtropical crop-livestock system. Agron Sustain Dev 39:26. https:// doi.org/10.1007/s13593-019-0573-3

Sartor LR, Sandini IE, Adami PF, Novakowiski JH, Ruthes BES (2018) Corn yield and grain nutritional status in a crop-livestock system with winter/summer nitrogen levels. Int J Plant Prod 12:309-314. https://doi.org/10.1007/s42106-018-0028-9

Silva SR, Gomes MJ, Dias-da-Silva A, Gil LF, Azevedo JMT (2005) Estimation in vivo of the body and carcass chemical composition of growing lambs by real-time ultrasonography1. J Anim Sci 83: 350-357. https://doi.org/10.2527/2005.832350x

Wilkinson JM, Lee MRF (2018) Review: Use of human-edible animal feeds by ruminant livestock. Animal 12:1735-1743. https://doi.org/ $10.1017 /$ S175173111700218X

Publisher's note Springer Nature remains neutral with regard to jurisdictional claims in published maps and institutional affiliations. 